\title{
Science journalism: The Arab boom
}

\section{As research increases in Arab countries, the media is stepping up to report on it. In the third of three essays, Nadia El-Awady says the local journalism has much room for improvement.}

W

hen I started covering science for IslamOnline.net in Egypt about ten years ago, I did an Internet search for 'science journalism' to see if such a profession even existed. I had not heard the two words put together before, at least not in an Arab context.

Things have changed. In 2006 I helped to launch the Arab Science Journalists Association (ASJA), which has since grown to 179 members as of May 2009. We are now co-bidding - with the US National Association of Science Writers - to host the 7th World Conference of Science Journalists in Cairo in 2011 (the 6th conference is being held in London next week). But as Arab science journalism gains strength, we need to ensure that its quality grows in step with its quantity.

Although the science staff of media organizations in the United States and Europe face cutbacks, a survey of ASJA members in January 2009 indicated that full-time jobs for Arab science journalists have remained relatively stable over the past five years, and freelancers report more opportunities. The Al-Ahram daily newspaper in Egypt, for example, which started a regular weekly science section in the 1950s, employs 20 full-time science journalists. The Washington Post, a US paper with a similar circulation, has eight. Al Jazeera, despite being one of the largest and most famous Arab news outlets, has no full-time science reporters, but Egypt's Al-Manara science research channel has 40 full-time staff. This promising situation is partly attributable to a heightened interest in science by Arab audiences, and a growing amount of scientific research and conferences in the region.

As local research is growing, Arab science-related institutions are showing greater interest in supporting media activities, in part to promote science and its communication. For instance, the Arab Science and Technology Foundation, based in Sharjah in the United Arab Emirates, finances many ASJA activities. And Egypt's Academy of Scientific Research and Technology funds the local Al-Ilm science magazine and Al-Manara's science channel. The funding and the acknowledgement of the importance of media are welcome, but there is need for caution. Journalists must be able to critically cover the institutions that fund them.

There is a deep reverence for scientists and doctors in Islamic cultures, so we need be careful

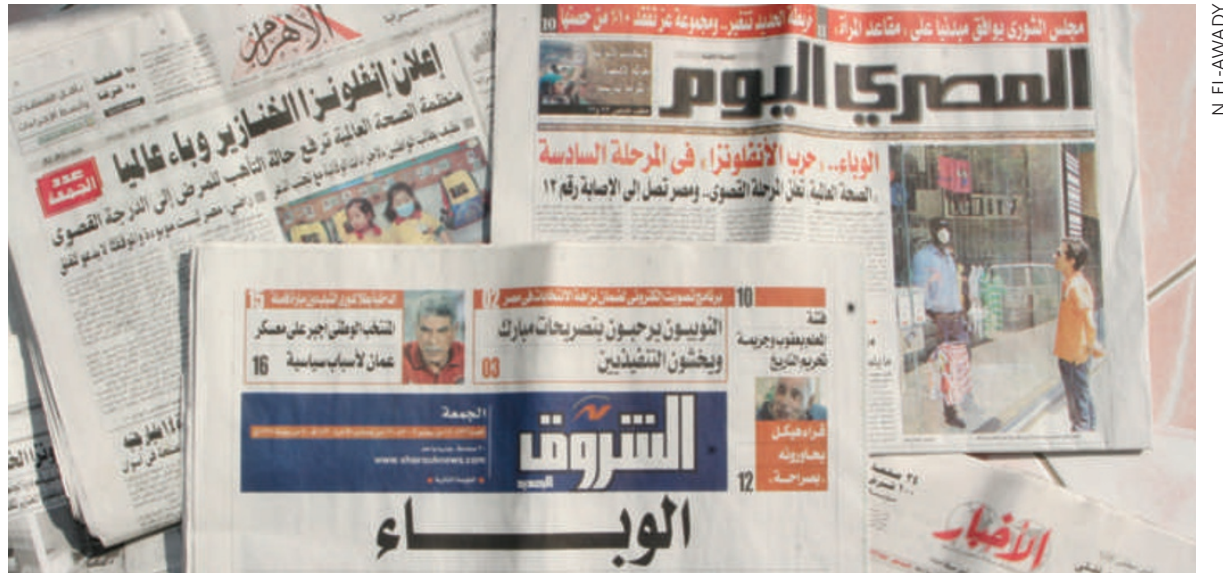

Science gets a good quantity of coverage in Arab papers, but is it good quality too?

that science journalists do not feel they owe a debt of gratitude to the very people that they should be investigating. Many science writers are also working scientists - one-fifth of ASJA's members have a faculty position, are working in research or are working doctors or veterinarians. This can make it hard to maintain a critical perspective in the journalistic work.

\section{Unintentional secrecy}

Despite these strong links between science and the media, Arab science institutions remain relatively closed to journalists. As I sit at my desk in Cairo, it is easier for me to know what is happening in American universities halfway across the globe than to know what is happening within the walls of Egypt's National Research Center

"Uncritical reporting of H1N1 policies by Egypt's media led to unnecessary panic." ism stems from a more general issue. Many media platforms are government-owned and, as a result, many journalists provide uncritical coverage of governmental announcements. The results can be seen, for example, in Egypt's recent coverage of the H1N1 'swine flu' outbreak. The country's pig population was slaughtered by presidential decree - despite no evidence of the virus in the pigs. Before a single $\mathrm{H} 1 \mathrm{~N} 1$ case had hit the country, to help limit infection Egypt's Minister of Health,
Hatem El-Gabaly, called for prayers and university exams to be held in open spaces rather than in mosques or enclosed rooms. Egyptian newspapers reported that the Ministry of Agriculture had banned all imports of pig gut and hair used in the manufacture of surgical threads and shaving brushes. Uncritical reporting of these policies by Egypt's media led to unnecessary panic among the general population.

Other factors compound these issues. A lack of English-language skills, combined with a lack of scientific sources in Arabic, limits available information and participation in international events. Some journalists and scientists in the region tend to consider the Internet in and of itself as a source of credible information.

Arab science journalists need to address these issues. They must diversify their funding and be mindful of the importance of distancing themselves from funding sources. Englishlanguage skills need enhancement and more training in Arabic should be available. Journalists and scientists need training on what are credible sources of information.

If we don't nurture and sustain the rise of Arab science journalism, and if we leave our weaknesses as they are, then that rise may be the harbinger of its downfall.

Nadia El-Awady is a freelance science journalist based in Cairo. She is a founding member and past president of the Arab Science Journalists Association and a board member of the World Federation of Science Journalists. e-mail: nadiaelawady@gmail.com See Books \& Arts, page 1061, and online at http://tinyurl.com/sciencejournalism. 